\title{
Mental Health Condition During COVID-19 Pandemic in Trained and Non-Trained Adults
}

\author{
Yonny Herdyanto $^{1 *}$, Nurhasan ${ }^{1}$, Muchamad Arif Al Ardha ${ }^{1}$, Dita Agustia ${ }^{1}$, Anindya \\ Mar'atus Sholikhah ${ }^{1}$, Lucy Widya Fathir ${ }^{1}$
}

${ }^{1}$ Faculty of Sport Science, Universitas Negeri Surabaya, Surabaya, Indonesia

*Corresponding Author. Email: yonnyherdyanto@unesa.ac.id

\begin{abstract}
The coronavirus disease 2019 (COVID-19) that becomes a global pandemic has set Indonesian government on high alert. This large-scale issue imposed enormous pressure on the government that leads to the issuance of nationwide distancing policy. The continuous spread of virus, quarantine, and stay-at-home orders for the long period of time contributing to adverse psychological impacts to society. This study investigated the mental health condition during COVID-19 pandemic in adults. This was a cross sectional study that collected demographic data and mental health measurements from April to June 2020. A total of 72 respondents consisted of physically trained and non-trained adults completed a selfadministered online-based survey and Depression, Anxiety, Stress Scale 42 (DASS 42) questionnaire. Independent TTest and Anova one way were performed to compare the psychological state between groups. The results showed that non-trained groups had higher level of stress ( $p$-value $0,009<0,05$ ) and anxiety ( $p$-value $0,009<0,05$ ). Findings highlight the importance of exercise to alleviate stress and anxiety. Further interventions and strategies should be done in order to mitigate the pandemic impacts on mental health.
\end{abstract}

Keywords: athlete, anxiety, COVID-19, depression, mental health, stress

\section{INTRODUCTION}

COVID-19 is a new disease that first occurred in late 2019 in Wuhan City in Central Hubei Province of China [1]. This virus was later become global pandemic that cause major impact on people's lives [2]. According to WHO report on June $27^{\text {th }} 2020$, the total confirmed infection of COVID19 reached 9 million people worldwide, with the global death toll passed 500.000 lives [3]. The increasing number has brought new challenges to public health matters [4] that leads authorities in many countries to implement social distancing policy, including Indonesia. In Indonesia, the virus has spread to all of the country's provinces with the number of infections has reached 50.000 cases in June 2020 since the first case emerged in March 2020 [5]. This number has set Indonesian government on high alert that lead them to extend the social restrictions policy to minimize the spread of virus.

The ongoing pandemic and social distancing policy rise significant concerns over how will the changes in the ways that people normally engage in daily routine affect their health and well-being [6]. It is especially relevant to people that practice quarantine or stay-at-home, where the feelings of stress, depression, anxiety or fear may develop [7]. The impact of this changes might cause psychological distress. This situation is worsened by hoax or false report that make people misunderstand and double their concern. Recent mental health studies on COVID-19 are more focusing on health professionals that is directly affected by the virus, or some particular age group such as students or elderly [8]. But in fact, psychological distress such as stress, depression, or anxiety not only experienced by those populations, but also in the general population [9]. The severity of the symptom is also affected by various demographic characteristics such as gender or place of origin, as stated by previous study that people living in urban areas, where the probabilities of encountering the virus are tend to develop higher level of depression [10].

The COVID-19 pandemic make a huge threat to global public health due to unprecedented individual and societal fear and anxiety. There are many methods for dealing with stress, such as music therapy [11], adequate rest [12], and exercise [13]. A reduction in physical activity and increased the sedentary lifestyle contribute to stress levels, 
which is associated with health-related quality of life [14]. Other coping behaviors that associate with decreased anxiety and depressive symptoms during pandemic are following healthy diet, doing hobbies, staying outdoor activity [15]. Large epidemiological studies suggest that better mental health is associated with physical activity and resilience to psychological distress, such as depression and anxiety symptoms [16]. There are many studies that investigate the association between exercise and psychological distress, and the previous meta-analysis study reveals a strong positive correlation between physical activity and mental health outcomes in adults and adolescents [17]. Physical activity also has a positive impact on mental health, improving mood, and also can be an effective way to dealing with depression and anxiety [18]. Regular exercise has benefit to human body and leads to good physiological changes. Regular aerobic exercise stimulates the action of hypothalamic-pituitary adrenal (HPA) to produce cortisol hormone [19]. The cortisol hormone functions to maintain and regulate vital functions such as the growth process, the reproductive system, and the body's response to stress and injury [20]. Physical activity can also release stress hormones by reducing excessive local inflammation within the respiratory tract and by inducing the secretion of anti-inflammatory cytokines, such as IL-4 and IL-10 [21].

Due to this beneficial effect on mental health, exercise has been proposed as a low-cost, effective nonpharmacological treatment for depression and anxiety [22]. Therefore, we conduct this study to analyze mental health conditions during COVID-19 pandemic in trained and nontrained adults.

\section{METHOD}

\section{A. Design and Sample}

This was a descriptive study with cross sectional design. This study was conducted from April to June 2020. The participants were gathered from sport community and nonsport community by using convenience sample method. A total of 72 adults aged 18-40 years old participated in this study. The respondents were then divided into trained and non-trained. "Trained" was defined based on these following criteria: (1) individuals with an extensive experience in sport or had a great competitive activity, showed by high performances reported in the field, e.g. participants to national or international level of sport competitions; (2) registered as an active member/athlete in sport community or organization such as PUSLATDA (Official Training Camp of Province Athlete), KONI (Sport Committee), and sport club.

\section{B. Data Collection}

Given the current situation, data were collected by using online questionnaire which was filled by individuals via online-based platform. The self-administered questionnaire instrument assessed demographic information, including age, gender, background (trained, non-trained), status (student, non-student), place of origin (within Surabaya city or from other cities), and living arrangement (living with parent, rent/boarding house, living independent). Respondents were also asked some questions about current experience related to COVID-19.

Stress and anxiety levels were assessed using Depression Anxiety Stress Scale (DASS) consisting of 42 questions. This questionnaire has been proven to be well-validated instrument to assess perceived depression symptoms. Respondents were asked to rate each question on 4-points scale ranging from 0 to 3 according to how often they experienced each statement during COVID-19 pandemic. The score was then accumulated and categorized with the cut-off to classify whether the respondents had depression, anxiety, or stress. The final composite score was then used to decide the levels of each mental health symptom which were: (1) no symptoms, (2) mild, (3) moderate, (4) severe and extremely severe.

\section{Data Analysis}

Data were analyzed using statistical software. Independent T-Test was performed to compare between two groups, while ANOVA one way was performed to compare between multiple groups. Chi Square test was applied to describe the demographic characteristic of the respondents. Data measurement were presented in mean and standard deviation $(\overline{\mathrm{x}} \pm \mathrm{SD})$. The significance level was set at $\alpha<0,05$ and all tests were two tailed.

\section{RESULT AND DISCUSSION}

A total of 72 people participated in this present study. Depression, anxiety, and stress were found in $27,8 \%$, $41,7 \%$, and $6,9 \%$ of the respondents, respectively (Table 1). The symptoms of the disorders were ranged from mild to severe and very severe. Anxiety was most likely found in respondents compared to depression and stress.

Table 1. Frequency of Depression, Anxiety, and Stress among Respondents

\begin{tabular}{lcccc}
\hline Category & Normal & Mild & Moderate & $\begin{array}{c}\text { Severe } \\
\text { \& } \\
\text { Very } \\
\text { Severe }\end{array}$ \\
\hline Depression & 52 & 14 & 6 & 0 \\
& $(72,2 \%)$ & $(19,4 \%)$ & $(8,3 \%)$ & \\
\hline Anxiety & 42 & 15 & 12 & 3 \\
& $(58,3 \%)$ & $(20,8 \%)$ & $(16,7 \%)$ & $(4,2 \%)$ \\
\hline
\end{tabular}




\begin{tabular}{lcccc}
\hline Category & Normal & Mild & Moderate & $\begin{array}{c}\text { Severe } \\
\text { \& } \\
\text { Very } \\
\text { Severe }\end{array}$ \\
\hline Stress & 67 & 3 & 1 & 1 \\
& $(93,1 \%)$ & $(4,1 \%)$ & $(1,4 \%)$ & $(1,4 \%)$ \\
\hline
\end{tabular}

The majority of participants were aged 20-29 years $(44,4 \%)$, male $(59,7 \%)$, coming from non-trained background (55,6\%), doing exercise 1-3 times a week $(40,3 \%)$, non-students $(52,8 \%)$, from within Surabaya city $(62,5 \%)$, and living with their parent $(66,7 \%)$.

Table 2. Depression Score between Groups

\begin{tabular}{lccc}
\hline \multicolumn{1}{c}{ Subgroup } & n & $\begin{array}{c}\text { Depression } \\
\text { Score }\end{array}$ & p-value \\
\hline Age & & & \\
$\quad$ 20 years & 21 & $4,67 \pm 4,08$ & \\
$20-29$ years & 32 & $4,81 \pm 4,49$ & 0,951 \\
30-39 years & 11 & $4,36 \pm 3,98$ & \\
$\quad$ 39 years & 8 & $3,88 \pm 4,52$ & \\
\hline Gender & & & \\
$\quad$ Male & 43 & $4,49 \pm 4,39$ & 0,792 \\
$\quad$ Female & 29 & $4,76 \pm 4,02$ & \\
\hline Background & & & \\
$\quad$ Trained & 32 & $2,94 \pm 3,21$ & $0,002^{*}$ \\
$\quad$ Non-trained & 40 & $5,92 \pm 4,49$ & \\
\hline Frequency & & &
\end{tabular}

\section{Frequency of}

exercise

\begin{tabular}{lccc} 
Never & 17 & $6,88 \pm 3,20$ & $0,009^{*}$ \\
1-3 times/week & 29 & $5,03 \pm 4,86$ & \\
4-5 times/week & 9 & $2,71 \pm 1,67$ & \\
Almost everyday & 17 & $2,44 \pm 3,72$ & \\
\hline Status & & & \\
$\quad$ Students & 34 & $5,85 \pm 4,25$ & $0,016^{*}$ \\
$\quad$ Non-students & 38 & $3,47 \pm 3,92$ & \\
\hline Place of origin & & & \\
$\quad$ Within Surabaya & 45 & $6,27 \pm 5,63$ & 0,099 \\
city & 27 & $8,56 \pm 5,60$ & \\
\hline
\end{tabular}

From other cities

\begin{tabular}{lccc}
\hline $\begin{array}{l}\text { Living } \\
\text { arrangements }\end{array}$ & & & \\
$\quad$ Living with & 48 & $4,90 \pm 4,31$ & \\
parent & 7 & $5,29 \pm 5,38$ & 0,447 \\
$\quad$ Rent/boarding & 17 & $3,47 \pm 3,43$ & \\
house & & & \\
$\quad$ Independent & & \\
significant at 0,05 & & \\
Depression score was showed in mean \pm SD
\end{tabular}

Across both groups, mean depression score was higher in respondents aged 20-29 years, female, never exercised, non-trained, respondent who was still a student, from other cities, and those who were living with parent. But significant differences were only found in non-trained, never exercised, and students, with $\mathrm{p}=0,002, \mathrm{p}=0,009$, and $\mathrm{p}=0,016$, respectively. As frequency of exercise increased, the mean score of depression significantly decreased (Table 2).
Table 3. Anxiety Score between Group

\begin{tabular}{lccc}
\hline \multicolumn{1}{c}{ Subgroup } & $\mathbf{n}$ & $\begin{array}{c}\text { Anxiety } \\
\text { Score }\end{array}$ & p-value \\
\hline Age & & & \\
$<20$ years & 21 & $6,19 \pm 4,12$ & \\
$20-29$ years & 32 & $7,16 \pm 4,73$ & 0,154 \\
30-39 years & 11 & $4,55 \pm 3,14$ & \\
$>39$ years & 8 & $4,00 \pm 3,70$ & \\
\hline Gender & & & \\
$\quad$ Male & 43 & $5,67 \pm 3,93$ & 0,284 \\
$\quad$ Female & 29 & $6,79 \pm 4,83$ & \\
\hline Background & & & \\
$\quad$ Trained & 32 & $4,66 \pm 3,65$ & $0,009^{*}$ \\
$\quad$ Non-trained & 40 & $7,30 \pm 4,49$ & \\
\hline
\end{tabular}

\begin{tabular}{lccc}
\hline $\begin{array}{l}\text { Frequency of } \\
\text { exercise }\end{array}$ & & & \\
$\quad$ Never & 17 & $9,18 \pm 3,73$ & $0,004^{*}$ \\
$1-3$ times/week & 29 & $5,83 \pm 4,43$ & \\
$4-5$ times/week & 9 & $5,00 \pm 4,27$ & \\
$\quad$ Almost everyday & 17 & $4,18 \pm 3,25$ & \\
\hline $\begin{array}{l}\text { Status } \\
\quad \text { Students }\end{array}$ & 34 & $7,62 \pm 4,57$ & $0,005^{*}$ \\
$\quad$ Non-students & 38 & $4,79 \pm 3,65$ & \\
\hline $\begin{array}{l}\text { Place of origin } \\
\quad \text { Within Surabaya }\end{array}$ & 45 & $5,40 \pm 4,30$ & 0,065 \\
city & 27 & $7,33 \pm 4,14$ & \\
$\quad$ From other cities & & & \\
\hline Living & & & \\
arrangements & 48 & $6,52 \pm 4,46$ & \\
$\quad$ Living with parent & 7 & $7,43 \pm 4,93$ & 0,172 \\
$\quad$ Rent/boarding & 17 & $4,47 \pm 3,34$ & \\
house & & & \\
$\quad$ Independent & & & \\
*significant at 0,05 & & & \\
Anxiety score was showed in mean \pm SD &
\end{tabular}

The same results were found in mean anxiety score. It was higher in respondents aged 20-29 years, female, never exercised, non-trained and student respondents, respondent from other cities, and those who were living in rent/boarding house. But, the mean of anxiety score was significantly higher in non-trained $(\mathrm{p}=0,009)$, never exercised $(\mathrm{p}=0,004)$ and students $(\mathrm{p}=0,005)$ (Table 3$)$.

Table 4. Comparison of Stress Score between Group

\begin{tabular}{llcc}
\hline \multicolumn{1}{c}{ Subgroup } & $\mathbf{n}$ & $\begin{array}{c}\text { Stress } \\
\text { Score }\end{array}$ & p-value \\
\hline Age & & & \\
$\quad<20$ years & 21 & $6,57 \pm 5,34$ & \\
$20-29$ years & 32 & $8,78 \pm 6,33$ & 0,110 \\
$30-39$ years & 11 & $5,55 \pm 4,18$ & \\
$\quad>39$ years & 8 & $4,12 \pm 4,05$ & \\
\hline Gender & & & \\
$\quad$ Male & 43 & $7,00 \pm 5,65$ & 0,822 \\
$\quad$ Female & 29 & $7,31 \pm 5,84$ & \\
\hline Background & & & \\
$\quad$ Trained & 32 & $4,66 \pm 3,65$ & $0,009^{*}$ \\
$\quad$ Non-trained & 40 & $7,30 \pm 4,49$ & \\
\hline $\begin{array}{l}\text { Frequency of } \\
\text { exercise }\end{array}$ & & & 0,058 \\
\hline
\end{tabular}




\begin{tabular}{lccc}
\hline \multicolumn{1}{c}{ Subgroup } & n & $\begin{array}{c}\text { Stress } \\
\text { Score }\end{array}$ & p-value \\
\hline Never & 17 & $10,00 \pm 4,84$ & \\
$1-3$ times/week & 29 & $7,17 \pm 6,39$ & \\
4-5 times/week & 9 & $5,33 \pm 4,33$ & \\
Almost everyday & 17 & $5,12 \pm 4,94$ & \\
\hline Status & & & \\
$\quad$ Students & 34 & $8,85 \pm 6,37$ & $0,014^{*}$ \\
$\quad$ Non-students & 38 & $5,58 \pm 4,54$ & \\
\hline Place of origin & & & \\
$\quad$ Within Surabaya & 45 & $4,09 \pm 4,29$ & 0,189 \\
city & 27 & $5,44 \pm 4,04$ & \\
$\quad$ From other cities & & & \\
\hline Living & & & \\
arrangements & 48 & $7,50 \pm 5,78$ & \\
$\quad$ Living with & 7 & $8,71 \pm 7,85$ & \\
parent & 17 & $5,41 \pm 4,18$ & 0,321 \\
$\quad$ Rent/boarding & & & \\
house & & & \\
$\quad$ Independent & & & \\
*significant at 0,05 & & & \\
Stress score was showed in mean $\pm \mathrm{SD}$ &
\end{tabular}

The mean of stress score was also higher in respondents aged 20-29 years, female, non-trained and student respondents, respondent from other cities, and those who were living in rent/boarding house. But only non-trained $(\mathrm{p}=0,009)$ and students $(\mathrm{p}=0,014)$ that showed significant differences (Table 4).

The present study also showed that depression, anxiety, and stress were significantly associated with background and status (Table 2-4). Non-trained adults and students were likely to have higher score of depression, anxiety, and stress than trained adults and non-student respondents.

Higher prevalence of depression, anxiety, and stress symptoms were reported higher in females compared to males. It was in line with previous studies that found higher perceived stress level in females than males [23][25]. Many factors have been regarded or this gender difference, including biological and socio-cultural factors [26]. It is explained that there were more pressures put on females that they tend to ignore the stress as their stress is not considered as important as in males. It would lead females to be more emotionally unstable and more prone to stress and being depressed [23], [27]. In addition to that, females have a variety of stressors to deal with such as inequality, social expectation, menstruation cycle, and due to gender itself [28].

Exercise and physical activity have been known to elevate the feeling of well-being. The present study showed that respondents engaged in regular exercise had less depression, anxiety, and stress compared to those in peer group. Our findings were in an accordance to previous studies that found a correlation between anxiety symptom and physical inactivity [26], [29], [30].

Our findings revealed that students were more likely to had depression, anxiety, and stress compared to non-student respondents. A cross sectional study conducted in Malaysian population explained that higher prevalence of mental health symptoms in students could be attributed to academic life [31]. Psychological distress in students become growing concern for the past decade, especially during COVID-19 pandemic. UNICEF reported that students assigned to home-learning or distance-learning program during quarantine were more likely to develop stress [32]. Style of studying, academic overload, fear of failing in exams, and pressure to succeed were one of factors associated with stress in undergraduate students. These stressors could later affect students' academic performance [33]. Quarantine policy and the closure of universities were reported as major cause for students feeling isolated and cut from their social circles, beside the changes in environment. All of these factors contributed to mental health disorder in students [34].

Table 5. The Association between Individual Factor and Depression Level

\begin{tabular}{|c|c|c|c|c|c|c|c|}
\hline \multirow{3}{*}{ Subgroup } & \multicolumn{6}{|c|}{ Depression Level } & \multirow{3}{*}{ p-values } \\
\hline & \multicolumn{2}{|c|}{ Normal } & \multicolumn{2}{|c|}{ Mild } & \multicolumn{2}{|c|}{ Moderate } & \\
\hline & $\mathbf{N}$ & $\%$ & $\mathbf{N}$ & $\%$ & $\mathbf{N}$ & $\%$ & \\
\hline \multicolumn{8}{|l|}{ Age } \\
\hline$<20$ years & 17 & 32,7 & 3 & 21,4 & 1 & 16,7 & \\
\hline $20-29$ years & 22 & 42,3 & 8 & 57,1 & 2 & 33,3 & $0,049 *$ \\
\hline $30-39$ years & 8 & 15,4 & 3 & 21,4 & 0 & 0 & \\
\hline$>39$ years & 5 & 9,6 & 0 & 0 & 3 & 50 & \\
\hline \multicolumn{8}{|l|}{ Gender } \\
\hline Male & 31 & 59,6 & 7 & 50 & 5 & 83,3 & 0,379 \\
\hline Female & 21 & 40,4 & 7 & 50 & 1 & 16,7 & \\
\hline \multicolumn{8}{|l|}{ Background } \\
\hline Trained & 25 & 48,1 & 5 & 35,7 & 2 & 33,3 & 0,603 \\
\hline Non-trained & 27 & 51,9 & 9 & 64,3 & 4 & 66,7 & \\
\hline \multicolumn{8}{|l|}{ Frequency of exercise } \\
\hline Never & 10 & 19,2 & 7 & 50,0 & 0 & 0 & \\
\hline 1-3 times/week & 22 & 42,3 & 3 & 21,4 & 4 & 66,7 & 0,178 \\
\hline
\end{tabular}




\begin{tabular}{|c|c|c|c|c|c|c|c|}
\hline \multirow{3}{*}{ Subgroup } & \multicolumn{6}{|c|}{ Depression Level } & \multirow{3}{*}{ p-values } \\
\hline & \multicolumn{2}{|c|}{ Normal } & \multicolumn{2}{|c|}{ Mild } & \multicolumn{2}{|c|}{ Moderate } & \\
\hline & $\mathbf{N}$ & $\%$ & $\mathbf{N}$ & $\%$ & $\mathbf{N}$ & $\%$ & \\
\hline 4-5 times/week & 7 & 13,5 & 1 & 7,1 & 1 & 16,7 & \\
\hline Almost everyday & 13 & 25,0 & 3 & 21,4 & 1 & 16,7 & \\
\hline \multicolumn{8}{|l|}{ Status } \\
\hline Students & 22 & 42,3 & 10 & 71,4 & 2 & 33,3 & 0,119 \\
\hline Non-students & 30 & 57,7 & 4 & 28,6 & 4 & 66,7 & \\
\hline \multicolumn{8}{|l|}{ Place of origin } \\
\hline Within Surabaya city & 33 & 63,5 & 9 & 64,3 & 3 & 50 & 0,803 \\
\hline From other cities & 19 & 36,5 & 5 & 35,7 & 3 & 50 & \\
\hline \multicolumn{8}{|l|}{ Living arrangements } \\
\hline Living with parent & 35 & 67,3 & 10 & 71,4 & 3 & 50 & 0014 \\
\hline Rent / boarding house & 5 & 9,6 & 1 & 7,1 & 1 & 16,7 & 0,914 \\
\hline Independent & 12 & 23,1 & 3 & 21,4 & 2 & 33,3 & \\
\hline \multirow{2}{*}{\multicolumn{8}{|c|}{ Known people with COVID- }} \\
\hline & & & & & & & \\
\hline Yes & 25 & 48,1 & 8 & 57,1 & 4 & 66,7 & 0,614 \\
\hline No & 27 & 51,9 & 6 & 42,9 & 2 & 33,3 & \\
\hline \multicolumn{8}{|c|}{ Fear of COVID-19 infection } \\
\hline Yes & 43 & 82,7 & 11 & 78,6 & 6 & 100 & 0,486 \\
\hline No & 9 & 17,3 & 3 & 21,4 & 0 & 0 & \\
\hline Total & 52 & 72,2 & 14 & 19,4 & 6 & 8,3 & - \\
\hline
\end{tabular}

*significant at 0,05

The majority of respondents were at normal depression level (Table 5). Bivariate analysis suggested that depression level was only associated with age group $(p=0,049)$. There were no association between depression level and other individual factors such as gender, background, frequency of exercise, status, place of origin, living arrangements, known people with COVID-19 positive, and fear of COVID-19 infection ( $p>0,05)$.

Table 6. The Association between Individual Factor and Anxiety Level

\begin{tabular}{|c|c|c|c|c|c|c|c|c|c|}
\hline \multirow{3}{*}{ Subgroup } & \multicolumn{8}{|c|}{ Anxiety Level } & \multirow{3}{*}{ p-value } \\
\hline & \multicolumn{2}{|c|}{ Normal } & \multicolumn{2}{|c|}{ Mild } & \multicolumn{2}{|c|}{ Moderate } & \multicolumn{2}{|c|}{$\begin{array}{c}\text { Severe \& Very } \\
\text { Severe }\end{array}$} & \\
\hline & $\mathbf{N}$ & $\%$ & $\mathbf{N}$ & $\%$ & $\mathbf{N}$ & $\%$ & $\mathbf{N}$ & $\%$ & \\
\hline \multicolumn{10}{|l|}{ Age } \\
\hline$<20$ years & 13 & 31,0 & 4 & 26,7 & 3 & 25,0 & 0 & 0 & \\
\hline $20-29$ years & 15 & 35,7 & 8 & 53,3 & 7 & 58,3 & 0 & 0 & 0,572 \\
\hline $30-39$ years & 8 & 19,0 & 3 & 20,0 & 0 & 0 & 0 & 0 & \\
\hline$>39$ years & 6 & 14,3 & 0 & 0 & 2 & 16,7 & 0 & 0 & \\
\hline \multicolumn{10}{|l|}{ Gender } \\
\hline Male & 26 & 61,9 & 11 & 73,3 & 5 & 41,7 & 0 & 0 & 0,292 \\
\hline Female & 16 & 38,1 & 4 & 26,7 & 7 & 58,3 & 0 & 0 & \\
\hline \multicolumn{10}{|l|}{ Background } \\
\hline Trained & 24 & 57,1 & 4 & 26,7 & 4 & 33,3 & 0 & 0 & $0,050 *$ \\
\hline Non-trained & 18 & 42,9 & 11 & 73,3 & 8 & 66,7 & 0 & 0 & \\
\hline \multicolumn{10}{|l|}{ Frequency of exercise } \\
\hline Never & 3 & 7,1 & 7 & 46,7 & 5 & 41,7 & 2 & 66,7 & \\
\hline 1-3 times/week & 18 & 42,9 & 6 & 40,0 & 4 & 33,3 & 1 & 33,3 & $0,006^{*}$ \\
\hline 4-5 times/week & 6 & 14,3 & 0 & 0 & 3 & 25,0 & 0 & 0 & \\
\hline Almost everyday & 15 & 35,7 & 2 & 13,3 & 0 & 0 & 0 & 0 & \\
\hline \multicolumn{10}{|l|}{ Status } \\
\hline Students & 18 & 42,9 & 7 & 46,7 & 6 & 50,0 & 0 & 0 & 0,294 \\
\hline Non-students & 24 & 57,1 & 8 & 53,3 & 6 & 50,0 & 0 & 0 & \\
\hline \multicolumn{10}{|l|}{ Place of origin } \\
\hline Within Surabaya city & 27 & 64,3 & 13 & 86,7 & 3 & 25,0 & 2 & 66,7 & $0,012 *$ \\
\hline From other cities & 15 & 35,7 & 2 & 13,3 & 9 & 75,0 & 1 & 33,3 & \\
\hline \multicolumn{10}{|l|}{ Living arrangements } \\
\hline Living with parent & 26 & 61,9 & 10 & 66,7 & 10 & 83,3 & 0 & 0 & 0,554 \\
\hline Rent / boarding house & 4 & 9,5 & 1 & 6,7 & 1 & 8,3 & 0 & 0 & \\
\hline
\end{tabular}




\begin{tabular}{|c|c|c|c|c|c|c|c|c|c|}
\hline \multirow{3}{*}{ Subgroup } & \multicolumn{8}{|c|}{ Anxiety Level } & \multirow{3}{*}{ p-value } \\
\hline & \multicolumn{2}{|c|}{ Normal } & \multicolumn{2}{|c|}{ Mild } & \multicolumn{2}{|c|}{ Moderate } & \multicolumn{2}{|c|}{$\begin{array}{c}\text { Severe \& Very } \\
\text { Severe }\end{array}$} & \\
\hline & $\mathbf{N}$ & $\%$ & $\mathbf{N}$ & $\%$ & $\mathbf{N}$ & $\%$ & $\mathbf{N}$ & $\%$ & \\
\hline Independent & 12 & 28,6 & 4 & 26,7 & 1 & 8,3 & 0 & 0 & \\
\hline \multicolumn{10}{|c|}{$\begin{array}{l}\text { Known people with COVID- } \\
19 \text { positive infection }\end{array}$} \\
\hline Yes & 22 & 52,4 & 9 & 60 & 4 & 33,3 & 2 & 66,7 & 0,511 \\
\hline No & 20 & 47,6 & 6 & 40 & 8 & 66,7 & 1 & 33,3 & \\
\hline \multicolumn{10}{|c|}{ Fear of COVID-19 infection } \\
\hline Yes & 34 & 81,0 & 12 & 80,0 & 11 & 91,7 & 3 & 100,0 & 0,684 \\
\hline No & 8 & 19,0 & 3 & 20,0 & 1 & 8,3 & 0 & 0 & \\
\hline Total & 42 & 58,3 & 15 & 20,8 & 12 & 16,7 & 3 & 4,2 & - \\
\hline
\end{tabular}

*significant at 0,05

The majority of respondents were not suffered from anxiety (Table 6). Further statistical analysis confirmed that the anxiety level was associated with background $(\mathrm{p}=0,050)$, frequency of exercise $(\mathrm{p}=0,006)$, and place of origin $(p=0,012)$. There were no association between anxiety level and other individual factors $(\mathrm{p}>0,05)$.

Table 7. The Association between Individual Factor and Stress Level

\begin{tabular}{|c|c|c|c|c|c|c|c|c|c|}
\hline \multirow{3}{*}{ Subgroup } & \multicolumn{8}{|c|}{ Stress Level } & \multirow{3}{*}{ p-value } \\
\hline & \multicolumn{2}{|c|}{ Normal } & \multicolumn{2}{|c|}{ Mild } & \multicolumn{2}{|c|}{ Moderate } & \multicolumn{2}{|c|}{$\begin{array}{c}\text { Severe \& Very } \\
\text { Severe }\end{array}$} & \\
\hline & $\mathbf{N}$ & $\%$ & $\mathbf{N}$ & $\%$ & $\mathbf{N}$ & $\%$ & $\mathbf{N}$ & $\%$ & \\
\hline \multicolumn{10}{|l|}{ Age } \\
\hline$<20$ years & 19 & 28,4 & 2 & 66,7 & 0 & 0 & 0 & 0 & \multirow{4}{*}{0,838} \\
\hline $20-29$ years & 29 & 43,3 & 1 & 33,3 & 1 & 100,0 & 1 & 100,0 & \\
\hline $30-39$ years & 11 & 16,4 & 0 & 0 & 0 & 0 & 0 & 0 & \\
\hline$>39$ years & 8 & 11,9 & 0 & 0 & 0 & 0 & 0 & 0 & \\
\hline \multicolumn{10}{|l|}{ Gender } \\
\hline Male & 39 & 58,2 & 3 & 100,0 & 1 & 100,0 & 0 & 0 & \multirow[t]{2}{*}{0,236} \\
\hline Female & 28 & 41,8 & 0 & 0 & 0 & 0 & 1 & 100,0 & \\
\hline \multicolumn{10}{|l|}{ Background } \\
\hline Trained & 31 & 46,3 & 1 & 33,3 & 0 & 0 & 0 & 0 & \multirow[t]{2}{*}{0,606} \\
\hline Non-trained & 36 & 53,7 & 2 & 66,7 & 1 & 100,0 & 1 & 100,0 & \\
\hline \multicolumn{10}{|l|}{ Frequency of exercise } \\
\hline Never & 16 & 23,9 & 0 & 0 & 1 & 100,0 & 0 & 0 & \multirow{4}{*}{0,686} \\
\hline 1-3 times/week & 26 & 38,8 & 2 & 66,7 & 0 & 0 & 1 & 100,0 & \\
\hline 4-5 times/week & 9 & 13,4 & 0 & 0 & 0 & 0 & 0 & 0 & \\
\hline Almost everyday & 16 & 23,9 & 1 & 33,3 & 0 & 0 & 0 & 0 & \\
\hline \multicolumn{10}{|l|}{ Status } \\
\hline Students & 30 & 44,8 & 2 & 66,7 & 1 & 100,0 & 1 & 100,0 & \multirow[t]{2}{*}{0,415} \\
\hline Non-students & 37 & 55,2 & 1 & 33,3 & 0 & 0 & 0 & 0 & \\
\hline \multicolumn{10}{|l|}{ Place of origin } \\
\hline Within Surabaya city & 44 & 65,7 & 0 & 0 & 0 & 0 & 1 & 100,0 & \multirow[t]{2}{*}{$0,028 *$} \\
\hline From other cities & 23 & 34,3 & 3 & 100,0 & 1 & 100,0 & 0 & 0 & \\
\hline \multicolumn{10}{|l|}{ Living arrangements } \\
\hline Living with parent & 44 & 65,7 & 3 & 100,0 & 0 & 0 & 1 & 100,0 & \multirow{3}{*}{0,076} \\
\hline Rent / boarding house & 6 & 9,0 & 0 & 0 & 1 & 100,0 & 0 & 0 & \\
\hline Independent & 17 & 25,4 & 0 & 0 & 0 & 0 & 0 & 0 & \\
\hline \multicolumn{10}{|c|}{ Known people with COVID- } \\
\hline $\begin{array}{l}19 \text { positive iniection } \\
\text { Yes }\end{array}$ & 34 & 50,7 & 2 & 66,7 & 0 & 0 & 1 & 100,0 & \multirow[t]{2}{*}{0,514} \\
\hline No & 33 & 49,3 & 1 & 33,3 & 1 & 100,0 & 0 & 0 & \\
\hline \multicolumn{10}{|c|}{ Fear of COVID-19 infection } \\
\hline Yes & 56 & 83,6 & 2 & 66,7 & 1 & 100,0 & 1 & 100,0 & \multirow[t]{2}{*}{0,801} \\
\hline No & 11 & 16,4 & 1 & 33,3 & 0 & 0 & 0 & 0 & \\
\hline Total & 67 & 93,0 & 3 & 4,2 & 1 & 1,4 & 1 & 1,4 & - \\
\hline
\end{tabular}

*significant at 0,05 
The present study reported that most of respondents were not suffered from stress during COVID-19 pandemic. A significant association was found between stress level and place of origin $(\mathrm{p}=0,028)$, while other individual factors such as age, gender, background, frequency of exercise, status, living arrangements, known people with COVID-19 positive, and fear of COVID-19 infection were not associated with stress level ( $p>0,05)$ (Table 7).

People well-being and mental health are becoming trending issues faced by societies nowadays, especially during pandemic. This study described levels of depression, anxiety, and stress in adults. DASS 42 was used as screening instrument to measure mental health condition and its severity during COVID-19 pandemic. Scores of moderate to severe and very severe of each symptom indicated a mental state that required an intervention [35]. In this study, we found that $8,3 \%, 16,7 \%$, and $1,4 \%$ of respondents had moderate level of depression, anxiety, and stress, respectively. While $4,2 \%$ and $1,4 \%$ of respondents suffered from severe/very severe level of anxiety and stress, respectively. Our study revealed that anxiety was the most common symptom found in respondents. It was compatible with previous literature studies in which the prevalence of anxiety were higher than depression [26], [30], [36].

In term of background, there were significant differences of depression, anxiety, and stress level between athlete and non-athlete. The frequency of exercise also showed significant different. Respondent who never exercise had higher depression, anxiety, and stress level than those practiced regular exercise daily. Trained adults were more physically active than their non-trained peers, thus they had lower depression, anxiety, and stress score.

Exercise is found to be an effective way to decrease depression, anxiety and stress level with no side effect comparing with drug consumption [37]. Exercise regularly can improve physical health, life satisfaction, and psychological well-being. Meanwhile, in contrast, people who rarely doing exercise will have psychological disorder. Several studies support that exercise as an alternative treatment for depression [38]. Exercise can be used to treat depression, whether performed at low, moderate, or vigorous intensity is effective in treating mild to moderate depression and is at least effective treatment [39]. The meta-analysis of jogger and walker respondent found that higher intensity exercise group was more effective to reduce symptom anxiety than lower intensity exercise group.

Several plausible mechanisms to explain how exercise and physical activity affect depression have been suggested. Physical activity may have physiological mechanism on depression due to the rise in releasing of $\beta$-endorphins and brain neurotransmitters such as dopamine, serotonin, and norepinephrine [40]. Another possible explanation is that exercise plays a role as an important buffer against stressful events and reduces emotional strain [41].

Exercise is found to be effective in the treatment of anxiety and both physiological and psychological pathway. Exercise has maintained a stable mood and controlled anxiety, including healthy eating and a regular routine of home-based cardiovascular and endurance muscular exercise [36]. 5-hydroxytriptamine turnover is increased in physical activity, while other studies have found that increase in atrial natriuretic peptide are associated with decrease anxiety levels. [42]. In another study showed that exercise with 30 minutes duration a day, four times a week, has the same effect as taking antidepressant drugs in reducing depression and anxiety level. That is why exercise has a positive effect on the therapeutic response in the treatment of depression [37].

Exercise has a major impact on brain memory in the learning process, protecting nerves, and reduce depression. It can also influence the synaptic structure and potential synaptic strength by strengthening the neurogenesis system, metabolic system, and vascular system [43]. Physical exercise can reduce nervous tension and reduce resting heart rate. It is indicating a decrease of the sympathetically mediated cardiovascular response to psychophysical stress. Such neuroendocrine action has been considered a mechanism to explain the effects of exercise on mood and depression. In the other hand, exercise can induced hypothalamic-pituitary-adrenal axis that regulates the stress response. [44]. The potential effects of exercise are neurotransmitter release, neurotrophic factor and neurogenesis, and cerebral blood flow alteration [45].

The perspective of this study is people who actively exercise (trained people or athletes) have to maintain their physical activity habits, and people who are inactive in exercise should start a physically active lifestyle. Introducing the benefit of exercise in the community is a strategy to improve physical as well as mental health [46].

\section{CONCLUSION}

Both trained and non-trained adults were at risk to suffered from mental health symptoms. These findings reinforce the need to practice regular exercise (such as home based cardiovascular and endurance muscular exercise) during COVID-19 pandemic to alleviate depression, stress and anxiety. But whether they used exercise as a coping style required further studies. Moreover, further interventions and strategies should be done in order to mitigate the pandemic impacts on mental health. 


\section{REFERENCES}

[1] H. Zhu and P. Niu, "The novel coronavirus outbreak in Wuhan, China," Glob. Heal. Res. Policy, vol. 5, no. 6, 2020, doi: 10.1186/s41256-020-00135-6.

[2] D. Roy, S. Tripathy, S. K. Kar, N. Sharma, S. K. Verma, and V. Kaushal, "Study of knowledge, attitude, anxiety \& perceived mental healthcare need in Indian population during COVID-19 pandemic," Asian J. Psychiatr., vol. 51, p. 102083 , Jun. 2020, doi: 10.1016/j.ajp.2020.102083.

[3] WHO, "Coronavirus disease situation report - 159," $2020 . \quad$ https://www.who.int/docs/defaultsource/coronaviruse/situation-reports/20200627covid-19-sitrep-159.pdf?sfvrsn=93e027f6_2 (accessed Jul. 07, 2020).

[4] R. Djalante et al., "Review and analysis of current responses to COVID-19 in Indonesia: Period of January to March 2020," Prog. Disaster Sci., vol. 6, p. 100091, 2020, doi: 10.1016/j.pdisas.2020.100091.

[5] Kemenkes, "Situasi Terkini Perkembangan Coronavirus Disease (COVID-19) 16 Maret 2020," 2020. https://covid19.kemkes.go.id/situasi-infeksiemerging/info-corona-virus/situasi-terkiniperkembangan-coronavirus-disease-covid-19-16maret-2020/\#.X3nD_mgzaUk (accessed Jun. 05, 2020).

[6] R. Stanton et al., "Depression, anxiety and stress during COVID-19: Associations with changes in physical activity, sleep, tobacco and alcohol use in Australian adults," Int. J. Environ. Res. Public Health, vol. 17, no. 11, pp. 1-13, 2020, doi: 10.3390/ijerph17114065.

[7] S. K. Brooks et al., "The psychological impact of quarantine and how to reduce," Lancet, vol. 395, no. March, pp. 912-920, 2020.

[8] C. Wang et al., "A longitudinal study on the mental health of general population during the COVID-19 epidemic in China," Brain. Behav. Immun., vol. 87, no. July, pp. 40-48, 2020, doi: 10.1016/j.bbi.2020.04.028.

[9] M. Casagrande, F. Favieri, R. Tambelli, and G. Forte, "The enemy who sealed the world: Effects quarantine due to the COVID-19 on sleep quality, anxiety, and psychological distress in the Italian population," Sleep Med., May 2020, doi: 10.1016/j.sleep.2020.05.011.

[10] S. Özdin and Ş. Bayrak Özdin, "Levels and predictors of anxiety, depression and health anxiety during COVID-19 pandemic in Turkish society: The importance of gender," Int. J. Soc. Psychiatry, vol. 66, no. 5, pp. 504-511, 2020, doi: $10.1177 / 0020764020927051$.

[11] F. N. Ogba, M. O. Ode, C. N. Onyishi, P. U. Agu, and E. Al., "Effectiveness of music therapy with relaxation technique on stress management as measured by perceived stress scale," Medicine (Baltimore)., vol. 98, no. 15, pp. 1-8, 2019, doi: 10.1097/MD.0000000000015107.
[12] D. W. Choi, S. Y. Chun, S. A. Lee, K. T. Han, and E. C. Park, "Association between Sleep Duration and Perceived Stress: Salaried Worker in Circumstances of High Workload," Int. J. Environ. Res. Public Health, vol. 15, no. 4, p. 796, 2018, doi: 10.3390/ijerph15040796.

[13] A. F. Garcia, C. M. Sabiston, and S. Brendon, "The evidence for physical activity in the management of major mental illnesses," Psychiatry, Med. Behav. Sci., vol. 32, no. 5, pp. 375-380, 2019, doi: 10.1097/YCO.0000000000000526.

[14] M. Qi, P. Li, W. Moyle, B. Weeks, and C. Jones, "Physical activity, health-related quality of life, and stress among the chinese adult population during the COVID-19 pandemic," Int. J. Environ. Res. Public Health, vol. 17, no. 18, pp. 1-10, 2020, doi: 10.3390/ijerph17186494.

[15] M. A. Fullana, D. Hidalgo-Mazzei, E. Vieta, and J. Radua, "Coping behaviors associated with decreased anxiety and depressive symptoms during the COVID-19 pandemic and lockdown," J. Affect. Disord., vol. 275, no. April, pp. 80-81, 2020, doi: 10.1016/j.jad.2020.06.027.

[16] D. D. Callow et al., "The Mental Health Benefits of Physical Activity in Older Adults Survive the COVID-19 Pandemic," Am. J. Geriatr. Psychiatry, vol. 28, no. 10, pp. 1046-1057, 2020, doi: 10.1016/j.jagp.2020.06.024.

[17] M. Rodriguez-Ayllon et al., "Role of Physical Activity and Sedentary Behavior in the Mental Health of Preschoolers, Children and Adolescents: A Systematic Review and Meta-Analysis," Sport. Med., vol. 49, no. 9, pp. 1383-1410, 2019, doi: 10.1007/s40279-019-01099-5.

[18] J. Drannan, "The Relationship Between Physical Exercise and Job Performance: The Mediating Effects of Subjective Health and Good Mood," Arab. J. Bus. Manag. Rev., vol. 6, no. 6, pp. 1-6, 2016, doi: 10.4172/2223-5833.1000269.

[19] E. Anderson and J. L. Durstine, "Physical Activity, Exercise, and Chronic Diseases: A Brief Review," Sport. Med. Heal. Sci., vol. 1, no. 1, pp. 3-10, 2019, doi: 10.1016/j.smhs.2019.08.006.

[20] T. E. Nugroho, J. L. Pujo, and W. I. Nurcahyo, "Fisiologi dan Patofisiologi Aksis HipotalamusHipofisis-Adrenal," JAI (Jurnal Anestesiol. Indones., vol. 3, no. 2, Jul. 2011, doi: 10.14710/JAI.V3I2.6448

[21] G. Maugeri et al., "The impact of physical activity on psychological health during Covid-19 pandemic in Italy," Heliyon, vol. 6, no. 6, p. e04315, 2020, doi: 10.1016/j.heliyon.2020.e04315.

[22] G. Bond, R. Stanton, S. A. Wintour, S. Rosenbaum, and A. L. Rebar, "Do exercise trials for adults with depression account for comorbid anxiety? A systematic review," Mental Health and Physical Activity, vol. 18. Elsevier Ltd, p. 100320, Mar. 2020, doi: 10.1016/j.mhpa.2020.100320.

[23] M. G. Martin, "Comparing stress levels and coping styles in college athletes and non-athletes," 
University of Tennessee, 2018.

[24] M. Mirzaei, S. M. Y. Ardekani, M. Mirzaei, and A. Dehghani, "Prevalence of depression, anxiety and stress among adult population: Results of yazd health study," Iran. J. Psychiatry, vol. 14, no. 2, pp. 137-146, 2019, doi: 10.18502/ijps.v14i2.993.

[25] R. Finnemore, "Perceptions of Stress Experienced by Student- Athletes in an Education Opportunity Program," 2017.

[26] G. Kaur, G. H. Tee, S. Ariaratnam, A. S. Krishnapillai, and K. China, "Depression, anxiety and stress symptoms among diabetics in Malaysia: A cross sectional study in an urban primary care setting," BMC Fam. Pract., vol. 14, no. 1, p. 1, 2013, doi: 10.1186/1471-2296-14-69.

[27] M. W. Matlin, The psychology of women, 7th editio. Belmont: Wadswortd, 2012.

[28] M. Calvarese, "The effect of gender on stress factors: An exploratory study among university students," Soc. Sci., vol. 4, no. 4, pp. 1177-1184, 2015, doi: 10.3390/socsci4041177.

[29] X. Hong et al., "Physical activity inversely associated with the presence of depression among urban adolescents in regional China," BMC Public Health, vol. 9, pp. 1-9, 2009, doi: 10.1186/14712458-9-148.

[30] A. K. Khuwaja, S. Lalani, R. Dhanani, I. S. Azam, G. Rafique, and F. White, "Anxiety and depression among outpatients with type 2 diabetes: A multicentre study of prevalence and associated factors," Diabetol. Metab. Syndr., vol. 2, no. 1, p. 72, 2010, doi: 10.1186/1758-5996-2-72.

[31] C. K. Teh, C. W. Ngo, R. A. binti Zulkifli, R. Vellasamy, and K. Suresh, "Depression, Anxiety and Stress among Undergraduate Students: A Cross Sectional Study," Open J. Epidemiol., vol. 5, no. 4, pp. 260-268, 2015, doi: 10.4236/ojepi.2015.54030.

[32] UNICEF, "Supporting your child's mental health as they return to school during COVID-19," 2020. https://www.unicef.org/coronavirus/supportingyour-childs-mental-health-during-covid-19-schoolreturn (accessed Aug. 03, 2020).

[33] H. F. Dalky and A. Gharaibeh, "Depression, anxiety, and stress among college students in Jordan and their need for mental health services," Nurs. Forum, vol. 54, no. 2, pp. 205-212, 2019, doi: 10.1111/nuf.12316.

[34] Z. L. Duraku and L. Hoxha, "The impact of COVID-19 on higher education: A study of interaction among students' mental health, attitudes toward online learning, study skills, and changes in students' life," 2020.

[35] N. Stormon, P. J. Ford, S. Kisely, E. Bartle, and D. S. Eley, "Depression, anxiety and stress in a cohort of Australian dentistry students," Eur. J. Dent. Educ., vol. 23, no. 4, pp. 507-514, 2019, doi:

\subsection{1/eje.12459.}

[36] C. Tovilla-Zárate et al., "Prevalence of anxiety and depression among outpatients with type 2 diabetes in the mexican population," PLoS One, vol. 7, no. 5, 2012, doi: 10.1371/journal.pone.0036887.

[37] G. Tasci, S. Baykara, M. G. Gurok, and M. Atmaca, "Effect of exercise on therapeutic response in depression treatment," Psychiatry Clin. Psychopharmacol., vol. 29, no. 2, pp. 137-143, Apr. 2019, doi: 10.1080/24750573.2018.1426159.

[38] P. J. Carek, S. E. Laibstain, and S. M. Carek, "Exercise for the treatment of depression and anxiety," Int. J. Psychiatry Med., vol. 41, no. 1, pp. 15-28, Jan. 2011, doi: 10.2190/PM.41.1.c.

[39] B. Helgadóttir, M. Hallgren, Ö. Ekblom, and Y. Forsell, "Training fast or slow? Exercise for depression: A randomized controlled trial," Prev. Med. (Baltim)., vol. 91, pp. 123-131, Oct. 2016, doi: 10.1016/j.ypmed.2016.08.011.

[40] L. L. Craft and F. M. Perna, "A Longitudinal Assessment of the Links Between Physical Activity and Self-Esteem in Early Adolescent Non-Hispanic Females," J Clin Psychiatry, vol. 6, no. 3, 2004.

[41] D. L. Schmalz, G. D. Deane, L. L. Birch, and E. Al, "A Longitudinal Assessment of the Links Between Physical Activity and Self-Esteem in Early Adolescent Non-Hispanic Females," J Adolesc Heal., vol. 41, no. 6, pp. 559-565, 2007, doi: 10.1016/j.jadohealth.2007.07.001.A.

[42] E. Aylett, N. Small, and P. Bower, "Exercise in the treatment of clinical anxiety in general practice - A systematic review and meta-analysis," BMC Health Services Research, vol. 18, no. 1. BioMed Central Ltd., pp. 1-18, Jul. 2018, doi: 10.1186/s12913-0183313-5.

[43] C. W. Cotman, N. C. Berchtold, and L. A. Christie, "Exercise builds brain health: key roles of growth factor cascades and inflammation," Trends in Neurosciences, vol. 30, no. 9. Elsevier Ltd, pp. 464472, 2007, doi: 10.1016/j.tins.2007.06.011.

[44] C. Nabkasorn, N. Miyai, A. Sootmongkol, and S. Junprasert, "Effects of physical exercise on depression, neuroendocrine stress hormones and physiological fitness in adolescent females with depressive symptoms | European Journal of Public Health | Oxford Academic," Eur. J. Public Health, pp. 179-184, Apr. 2006.

[45] A. Deslandes et al., "Exercise and mental health: Many reasons to move," Neuropsychobiology, vol. 59, no. 4. Neuropsychobiology, pp. 191-198, Aug. 2009, doi: 10.1159/000223730.

[46] G. Mammen and G. Faulkner, "Physical activity and the prevention of depression: A systematic review of prospective studies," Am. J. Prev. Med., vol. 45, no. 5, pp. 649-657, Nov. 2013, doi: 10.1016/j.amepre.2013.08.001. 